\title{
Analysis of the Process of Real Estate Disposal by Public Tender and Related Legal and Surveying Actions on the Example of the City of Krakow**
}

\section{Introduction}

Disposal of the properties belonging to the resources of the State Treasury and local government units should be conducted in such a way as to enable a general and public selection of the buyer. A form of public selection of the buyer is a tender, the principles and basic rules of which, when dealing with a property belonging to the resources listed above, have been defined in the Act of 21 August 1997 on real estate management (further referred to as the Real Estate Management Act) [11].

The purpose of this paper is to analyze the process of sale by public tender of the real estate owned by the City of Krakow in the period 2010-2012, including in particular:

- type of the property sold, its area and use,

- stages of the tendering procedure,

- City budget revenues from selling real estate by tender,

- number of negative results of tenders,

- legal and surveying activities necessary for proper handling of the tender procedure.

The source materials were the provisions of law, the subject literature and the results of the research from statutory resources, conducted at the Department of Treasury's Office of the City of Krakow.

* AGH University of Science and Technology, Faculty of Mining Surveying and Environmental Engineering, Department of Surveying Engineering and Construction, Krakow, Poland

** Work carried out within the statutory research of the Department of Surveying Engineering and Construction no. 11.11.150. 005 


\section{Tender as the Primary Mode of Public Property Disposal}

In the case of the management of real property owned by the State Treasury or local government units, special procedures are applied, which were specified in the above-mentioned Real Estate Management Act.

A basic procedure for the sale of property rights (as well as rights to perpetual usufruct of the State Treasury or local government units) or lease of a property in the public domain, is a tender.

A detailed manner and procedure for disposing of properties by means of public tenders has been set out in the Regulation of the Council of Ministers of 14 September 2004 on the procedures for conducting tenders and negotiations for the sale of real properties [6], which came into force on 22 September 2004.

The subject of the study are the procedures regarding tenders on properties from public resources which are managed by the governor and the executive bodies of local government units. A different mode of conducting tenders for the sale of agricultural land which is owned by the State Treasury was regulated in the Act of 19 October 1991 on the management of agricultural land owned by the State Treasury [10] and the ordinance of the Council of Ministers of 30 April 2012 on detailed procedures for the sale of properties which belong to the Agricultural Property Resources of the State Treasury and of their components, lowering of the selling price for the property entered in the register of monuments, and estimated rates for land [8]. Tenders for these real properties are organized by the Agricultural Property Agency. In contrast, the properties held by the Military Property Agency are sold according to the procedure laid down in the Act on Real Estate Management.

\section{Stages of the Tendering Procedure}

The tender procedure for the sale of a public property is a long and formal process, comprising a number of stages. The process involves surveyors drawing up legal and surveying documents, as well as representing the promoters of the tender.

\subsection{Surveying and Legal Actions before the Commencement of the Tender Procedure}

The main stages of the tender procedure, such as public announcement, checking priority rights, information on the tender, result from the above-mentioned provisions. This paper suggests other surveying and legal actions listed in clauses a), h) and j), which do not arise directly from these norms, but which, in the author's opinion, condition a proper course of the process. The explanation of all the aspects of the legal and factual status of the property, and taking appropriate actions before the start of the tendering procedure, eliminates the problems hindering the successful 
conclusion of an agreement with the buyer selected during the tender. It also limits the claims directed to public entities.

The analysis of the process of real estate disposal by means of tenders in the City of Krakow allowed to identify the scope and nature of surveying and legal actions to be taken before the commencement of the tender procedure. These include:

a) Examination of the current legal status of the property on the basis of land and mortgage register, cadastre and other documents. Particular attention should be given to the provisions of Section III of the land and mortgage register regarding, for example, warnings about the non-compliance of the legal status described in the register with the actual legal status. Such records exclude the reliability of the data contained in this land and mortgage register.

b) Achieving a compliance of the data contained in the land and mortgage register and in the cadastre regarding the objective and subjective scope. For this purpose, it may be necessary to draw up surveying and legal documents (such as the Land Use Changes, synchronization lists) and the disclosure of other documents defining the actual legal status of the real property in the above systems, as well as the designation of the property resulting from, for example, a conducted division.

c) Defining the use of the property in the local zoning plan. If the public property intended for sale is not covered by the plan (e.g. current zoning plans cover $40.3 \%$ of the area of Krakow), it is justified to obtain a zoning permit. It will allow us to determine the potential possibility for the development of the property by the purchaser. This decision will also help to determine the value of the property and, as a consequence, of the starting price in the tender at a higher level.

d) Determining the course of property boundaries. In order to determine property boundaries, a resumption procedure for the boundary points can be used, and if there is a dispute, disputed areas demarcation will be necessary.

e) Examination of claims by former owners. To do this, it is necessary to check the legal basis of the real estate acquisition by the local government unit, as well as of the legal predecessor, if it was the Treasury. In the case of a purchase of a real property under expropriation, article 136 of the Real Estate Management Act will apply, according to which the expropriated property can not be used for the purpose other than that specified in the decision on expropriation, on condition that the previous owner does not request a refund. In the case of an intention of adopting the expropriated property or part thereof for another purpose, a competent authority shall notify the previous owner or their heirs of the possibility of restitution. In the case of a failure to apply for restitution of the expropriated property within three months from the date of the receipt of a notice, the right to the property restitution expires. Only then the real property can be disposed of. 
f) Determining whether in relation to a property planned for sale there are no administrative proceedings concerning the validity of its acquisition by the State or a local government unit (e.g. proceedings for the annulment of an administrative decision on the basis of which the property was acquired for the resources of the Treasury or a local government). According to article 34 section 3 of the Real Estate Management Act, in this case the sale of the property may not be conducted. Violation of this rule of law gives rise to claims for damages. In the author's opinion, it should also be examined whether there are no court proceedings pending, e.g. to change the content of the land and mortgage register so that it is consistent with the actual legal status, or the resumption of legal proceedings in which the judgment was given on the acquisition of real property (e.g. judgment on real estate acquisitive prescription).

g) Provision of access to a public road. If a decision regarding land division in order to parcel out a property for a tender includes a condition that, when selling a parcelled out plot of land, road easement will be established to provide access to a public road, or there will be a sale of shares in an internal access road, the transfer agreement regarding the rights to the parcelled out plot without fulfilling such a condition is invalid (see the resolution of the Supreme Court of 4 June 2009, III CZP 34/09 (OSNC 2010/2/20). The conducted analysis confirms the incidence of two individual cases of refusal of concluding a deed by a notary public due to a failure to establish an easement.

h) Establishing a transmission easement for the entrepreneur who owns the utilities located on the property, which are used for providing or removing fluids, vapour, gas, electricity and others. (article 305 of the Civil Code). This will allow to avoid the common practice claims of prospective buyers to remove the devices, or for damages. In the analyzed period there were three cases regarding demands to remove the utilities or for compensation.

i) Permit issued by the Regional Conservator of Monuments regarding the disposal of a property entered in the register of monuments in accordance with article 13 section 4 of the Real Estate Management Act. This permit is issued in the form of an administrative decision.

j) A call for release of the property by the entities wielding a public property without a legal title. In practice, cases where individuals occupy a property owned by the City of Krakow are very common, sometimes leading to the acquisitive prescription. The buyer selected during a tender should take possession of the property without the burden of third parties. Within the analyzed period, in five cases it was necessary to apply for conveyance of the property.

k) Ordering a certified appraiser to execute a real estate appraisal study to determine its market value. 


\subsection{Publication of the List of Properties for Sale}

Pursuant to article 35 section 1 [11], the lists are displayed for a period of 21 days at the headquarters of the competent authority, and additionally, the information about the publication of the list shall be made public by an announcement in the local press, and in other ways customary in the locality, as well as on the websites of the competent authority.

Publication of the list of properties is to: preserve transparency of disposing of the properties owned by the State Treasury or local government units, to allow for the widest range of the interested entities to acquire relevant information about the property being sold, and to enable the persons entitled to preemptive rights to the acquisition of the property, pursuant to article 34 section 1 of the Real Estate Management Act.

The list includes as follows (article 35 section 2 [11]):

- property designation according to the land and mortgage register and the real estate cadastre,

- property area,

- description of the property,

- property intended use and its development,

- date of the property development (in the case of perpetual usufruct),

- price of the property (in the case of sale in a tendering procedure - the asking price),

- fee rates for perpetual usufruct in percentage,

- time limits for payment,

- rules for updating the fees,

- information on intention to sell, to deliver for perpetual usufruct,

- deadline for submission of an application by the persons who are entitled to preemptive rights to the acquisition of the property, pursuant to article 34 section 1 of the Real Estate Management Act [11].

\subsection{Examining Applications for the Preemptive Right to Acquisition of a Real Property}

Before the tender is announced, applications of the persons entitled to preemptive rights to acquire the property are being considered. These persons acquire the property without tender procedures.

In the case of a disposal of properties owned by the State Treasury or local government unit, the preemptive right to their acquisition is granted to persons who meet one of the following conditions set forth in article 34 section 1 of the Real Estate Management Act:

- they are entitled to a claim for the purchase of a property by virtue of the Real Estate Management Act or other regulations, if they submit an application before the deadline specified in the list, 
- they are former owners of the property being sold, deprived of the ownership of that property before 5 December 1990, or their successors, if they submit an application before the deadline specified in the list,

- they are a tenant of living premises, and the lease had been established for an indefinite period.

\subsection{Invitation to a Tender}

A tender may be announced no earlier than the expiry of the time provided for submitting applications regarding the use of the preemptive right. An invitation to a tender shall contain information that was included in the list of properties available to the public, and the time (defined date and hour), place (full address and designation of a room in which the tender will be held) and conditions of the tender, the amount of the security deposit, as well as the form and date of its submission. The invitation to a limited tender shall include justification for limiting the tender. One tender notice may include information on the sale of several properties. The invitation to the tender may not, however, include the dates of the subsequent tenders for the sale of the same property.

The method and deadline of public disclosure of the tender notice has been strictly defined in $\S 6$ of the Regulation, and it depends on the asking price of the property held for sale. Regardless of the asking price, each tender notice shall be posted on the website of the competent authority and shall be displayed on bulletin boards in the buildings of the competent authority.

The notice shall initiate the tender procedure.

\subsection{Pricing Rules for Tenders}

The price of the property shall be determined on the basis of its value as determined by a certified appraiser, applying the rules in force in this field, and included in articles 149-159 of the Real Estate Management Act.

The asking price in the first bidding shall be in the amount not less than the value of the property. This price may be equal to or greater than the value of the property determined by the appraiser. In practice, the asking price for an undeveloped land intended for development is set at the market value determined by the appraiser $+23 \%$ VAT, which is levied on the sale of such properties. In any case, however, the analysis of the real estate market and the potential interest in acquiring the property should be taken into account.

Pursuant to articles 39 and 67 section 2 [1], in the case when the first bidding ended up with a negative result, the starting price of the second bid can be established in the amount lower than its market value, but not less than $50 \%$ of this value.

If the second bid has not resulted in selecting a buyer either, the tender promoter may organize more bids and may reduce the asking price (it can not be less 
than $50 \%$ of the property value), or opt for the buyer to be determined under negotiation. The price fixed by negotiation shall not be less than $40 \%$ of the property value.

\subsection{The Bid Security Deposit}

A condition to participate in a tender is to provide a deposit. Detailed regulations regarding a security deposit as collateral of an agreement for the sale of real property by tender, pursuant to the provisions of article 42 section 2 clause 1 of the Real Estate Management Act [11], have been defined in $\S 4$ of the Regulation [4].

The competent authority shall determine the amount of the security deposit, which shall not be less than $5 \%$ and higher than $20 \%$ of the asking price of the property being sold.

\section{Analysis the Scope and Type of the Real Estate Owned by the City of Krakow and Sold by Tender}

The study included properties owned by the City of Krakow, which were sold by means of a tender in the last three years, i.e. from 2010 to 2012.

The conducted analysis involves a type of real properties, their use, their area, the municipal budget revenues from the sale, the number of bids and their results. The results have been shown in Tables $1-4$

Table 1. Quality of properties owned by the City of Krakow sold by tender the year 2010

\begin{tabular}{|l|c|c|c|c||}
\hline \multicolumn{1}{|c|}{$\begin{array}{c}\text { Real estate designation or } \\
\text { manner of land use }\end{array}$} & $\begin{array}{c}\text { Number of } \\
\text { properties }\end{array}$ & Area [ha] & $\begin{array}{c}\text { Usable floor area } \\
\text { of a building } \\
\text { (living unit) [m²] }\end{array}$ & $\begin{array}{c}\text { Selling price } \\
\text { [PLN] }\end{array}$ \\
\hline For multi-family housing & 2 & 0.0489 & - & 2442622.95 \\
\hline For service buildings & 5 & 0.2743 & - & 1538524.59 \\
\hline $\begin{array}{l}\text { Properties developed with } \\
\text { buildings }\end{array}$ & 4 & 0.6160 & 826.31 & 6198150.00 \\
\hline For single-family housing & 15 & 1.2798 & - & 3586800.34 \\
\hline Developed - garages & 15 & - & 310.28 & 378977.63 \\
\hline $\begin{array}{l}\text { Developed - commercial } \\
\text { premises }\end{array}$ & 7 & - & 196.86 & 114836.39 \\
\hline Developed - living premises & 22 & - & 1003.19 & 5689491.80 \\
\hline For communication purposes & 4 & 0.6861 & - & 1653459.02 \\
\hline Total & 74 & 2.9051 & 2336.64 & 21602862.72 \\
\hline
\end{tabular}

Source: own studies based on the data from the Department of Treasury's Office of the City of Krakow 
Table 2. Quality of properties owned by the City of Krakow sold by tender the year 2010

\begin{tabular}{||l|c|c|c|c||}
\hline $\begin{array}{c}\text { Real estate designation or manner } \\
\text { of land use }\end{array}$ & $\begin{array}{c}\text { Number of } \\
\text { properties }\end{array}$ & Area [ha ] & $\begin{array}{c}\text { Usable floor area } \\
\text { of a building } \\
\text { (living unit) [m²] }\end{array}$ & $\begin{array}{c}\text { Selling price } \\
\text { [PLN] }\end{array}$ \\
\hline \hline For multi-family housing & 2 & 1.0973 & - & 7926437.40 \\
\hline For service buildings & 5 & 0.2303 & - & 1234930.90 \\
\hline $\begin{array}{l}\text { Properties developed with } \\
\text { buildings }\end{array}$ & 9 & 1.6976 & 3857.58 & 10239642.00 \\
\hline For single-family housing & 19 & 1.5843 & - & 4408518.68 \\
\hline Developed - garages & 11 & - & 199.53 & 275401.45 \\
\hline Developed - commercial premises & 13 & - & 758.32 & 1681855.34 \\
\hline Developed - living premises & 2 & - & 86.46 & 559900.00 \\
\hline Total & 61 & 4.6095 & 4901.89 & 26326685.77 \\
\hline
\end{tabular}

Source: own studies based on the data from the Department of Treasury's Office of the City of Krakow

Table 3. Quality of properties owned by the City of Krakow sold by tender the year 2010

\begin{tabular}{||l|c|c|c|c||}
\hline $\begin{array}{c}\text { Real estate designation or manner } \\
\text { of land use }\end{array}$ & $\begin{array}{c}\text { Number of } \\
\text { properties }\end{array}$ & Area [ha ] & $\begin{array}{c}\text { Usable floor area } \\
\text { of a building } \\
\text { (living unit) [m²] }\end{array}$ & $\begin{array}{c}\text { Selling price } \\
\text { [PLN] }\end{array}$ \\
\hline For multi-family housing & 2 & 0.1206 & - & 2902739.84 \\
\hline For service buildings & 9 & 4.2210 & - & 7126887.66 \\
\hline $\begin{array}{l}\text { Properties developed with } \\
\text { buildings }\end{array}$ & 5 & - & 8882.63 & 29875070.00 \\
\hline For single-family housing & 8 & 0.2558 & - & 544506.76 \\
\hline To enlarge a neighboring property & 20 & 1.6084 & - & 3862841.95 \\
\hline Developed - garages & 8 & - & 206.72 & 243981.75 \\
\hline $\begin{array}{l}\text { Developed - commercial premises } \\
\text { including attics }\end{array}$ & 5 & - & 2069.30 & 5846000.00 \\
\hline Developed - living premises & 7 & - & 333.25 & 1862765.24 \\
\hline For communication purposes & 4 & 0.1648 & - & 298220.92 \\
\hline Total & 68 & 6.3706 & 11491.90 & 52563014.12 \\
\hline
\end{tabular}

Source: Own studies based on the data from the Department of Treasury's Office of the City of Krakow

The analysis of the tender results reveals that the largest proceeds in each year were obtained from the sale of real properties developed with buildings, whereas the lowest were obtained from the sale of garages (2011 and 2012) and commercial premises (2010). 
The largest land area (11.3136 hectares) was sold in 2012.

The total revenue from the sale by tender of real properties by the City of Krakow in the analyzed period of the three years amounts to 100492562.61 PLN, of which the amount of 52563 014.12 PLN was obtained in 2012.

Table 4. Number of open auctions for the sale of real properties of the City of Krakow in the period 2010-2112

\begin{tabular}{|c|c|c|c|c||}
\hline \multirow{2}{*}{ Period } & \multicolumn{3}{|c|}{ Number of tenders } & $\begin{array}{c}\text { The share of tenders completed } \\
\text { with negative results in the } \\
\text { total amount [\%] }\end{array}$ \\
\cline { 2 - 5 } & total & $\begin{array}{c}\text { completed with } \\
\text { negative results }\end{array}$ & $\begin{array}{c}\text { completed with } \\
\text { positive results }\end{array}$ & 75 \\
\hline \hline 2010 & 308 & 231 & 71 & 85 \\
\hline 2011 & 471 & 400 & 79 & 80 \\
\hline Total & 1163 & 305 & 227 & 80 \\
\hline
\end{tabular}

Source: own studies based on the data from the Department of Treasury's Office of the City of Krakow

The research shows that for a total of 1163 open tenders for the sale of real properties owned by the City of Krakow, as much as $80 \%$ had a negative result.

Analyzing the causes of low effectiveness of tenders in the studied period, the following problems can be identified:

- a decrease in the interest of potential buyers in purchasing a real property,

- reduction in loan availability and an increase in their costs,

- obligation to include VAT in the asking price.

For comparison, the results of the tenders conducted in the period of 2008-2009 were analyzed, which revealed that, during this period, $65 \%$ of the tenders ended with a negative result.

\section{Conclusions}

In the analyzed period, i.e. in the years 2010-2112, the city of Krakow gradually disposed of real properties of various uses to obtain the total proceeds to the budget amounting to 100492562.61 PLN, with over 52 million in 2012.

A lot of tenders ended up with a negative result (76\% in 2010, 85\% in 2011, 80\% in 2012) which led to the subsequent bids with lower starting price.

Based on the conducted research and the analysis of the provisions of law, the stages of the tender procedure on the sale of public property were specified. Also, surveying and legal actions were proposed which do not arise from the regulations but which, in the opinion of the author, are required to be carried out before the commencement of the tender procedure. 
A necessity was pointed out of an analysis on the regularity of the property acquisition by the State Treasury or by the local government unit of not only the administrative proceedings (which is imposed by article 34 section 3 of the Act on the Real Estate Management) but also of the court proceedings, for example, change the content of the land and mortgage register so that it is in compliance with the actual legal status, or the resumption of legal proceedings in which the judgment was given on the acquisition of real property (e.g. judgment on real estate acquisitive prescription).

It was proposed, inter alia, to establish a transmission easement in favor of the entrepreneur who owns the technical infrastructure located on the property, and providing access to a public road. It will help to eliminate the problems which hinder the execution of the notarial deed with the successful tenderer, as well as to limit damage claims directed to public entities.

\section{References}

[1] Bieniek G., Gdesz M., Kalus S., Matusik G., Mzyk E.: Ustawa o gospodarce nieruchomościami: komentarz [red. S. Kalus]. LexisNexis, Warszawa 2012.

[2] Bończak-Kucharczyk E.: Ustawa o gospodarce nieruchomościami: komentarz. Wolters Kluwer Polska, Warszawa 2013.

[3] Gdesz M., Trembecka A.: Regulowanie stanu prawnego nieruchomości pod drogi. Wydawnictwo Gall, Katowice 2011.

[4] Gdesz M., Trembecka A.: Publiczne prawo nieruchomości dla geodetów. Wydawnictwo Gall, Katowice 2013.

[5] Jaworski J., Prusaczyk A., Tułodziecki A., Wolanin M.: Ustawa o gospodarce nieruchomościami: komentarz. CH Beck, Warszawa 2009.

[6] Rozporzązenie Rady Ministrów z dnia 14 września 2004 r. w sprawie sposobu i trybu przeprowadzania przetargów oraz rokowań na zbycie nieruchomości. Dz. U. 2004, nr 207, poz. 2108.

[7] Rozporządzenie Rady Ministrów z dnia 21 września 2004 r. w sprawie wyceny nieruchomości i sporządzania operatu szacunkowego. Dz. U. 2004, nr 207, poz. 2109.

[8] Rozporządzenie Ministra Rolnictwa i Rozwoju Wsi z dnia 30 kwietnia 2012 r. w sprawie szczegótowego trybu sprzedaży nieruchomości Zasobu Własności Rolnej Skarbu Państwa i ich części składowych, warunków obniżenia ceny sprzedaży nieruchomości wpisanej do rejestru zabytków oraz stawek szacunkowych gruntów. Dz. U. 2012, nr 0, poz. 540.

[9] Ustawa z dnia 23 kwietnia 1964 r. - Kodeks cywilny. Dz. U. nr 16, poz. 93 with amendments.

[10] Ustawa z dnia 19 października 1991 r. o gospodarowaniu nieruchomościami rolnymi Skarbu Państwa. Dz. U. 2012, poz. 1187.

[11] Ustawa z dnia 21 sierpnia 1997 r. o gospodarce nieruchomościami. Dz. U. 2010, nr 102, poz. 651. 